\title{
DEGRADASI PENCEMAR ORGANIK DALAM LINDI DENGAN PROSES OKSIDASI LANJUT
}

\author{
N.W. Yuningrat ${ }^{1}$, I.M. Gunamantha ${ }^{2}$, N.M. Wiratini ${ }^{3}$ \\ 1, 2, 3Jurusan Analis Kimia, Fakultas MIPA, Universitas Pendidikan Ganesha, \\ Singaraja, Indonesia
}

e-mail: niwyuningrat@yahoo.com, wiliangga@yahoo.com

\begin{abstract}
Abstrak
Tujuan penelitian ini adalah (1) mengetahui karakteristik lindi di TPA Bengkala Singaraja berdasarkan rasio $\mathrm{BOD}_{5} / \mathrm{COD}$; (2) pengaruh penambahan penambahan katalis $\mathrm{TiO}_{2}$ terhadap efektivitas penyisihan $\mathrm{BOD}$ dan $\mathrm{COD}$ lindi dengan menggunakan proses oksidasi lanjut (AOP) sistem $\mathrm{UV} / \mathrm{H}_{2} \mathrm{O}_{2}$; (3) pengaruh $\mathrm{pH}$ campuran terhadap efektivitas penyisihan $B O D$ dan $C O D$ lindi dengan menggunakan $A O P$; (4) pengaruh konsentrasi $\mathrm{H}_{2} \mathrm{O}_{2}$ terhadap efektivitas penyisihan BOD dan COD lindi dengan menggunakan AOP; (5) waktu reaksi terhadap nilai BOD dan COD lindi dengan menggunakan AOP. Metode eksperimen digunakan untuk mendegradasi lindi dengan dan tanpa katalis dalam reaktor fotokimia. Hasil penelitian menunjukkan bahwa Lindi yang diambil dari cell landfill di TPA Bengkala Singaraja memiliki usia yang hampir matang berdasarkan perbandingan $\mathrm{BOD}_{5} / \mathrm{COD}$. Penambahan katalis $\mathrm{TiO}_{2}$ untuk pengolahan lindi dengan sistem $\mathrm{UV} / \mathrm{H}_{2} \mathrm{O}_{2}$ dapat meningkatkan efektivitas penyisihan BOD dan $\mathrm{COD}$ lindi. Efektivitas penyisihan BOD dan $\mathrm{COD}$ lindi dengan sistem $\mathrm{UV} / \mathrm{H}_{2} \mathrm{O}_{2}$ yang optimum terjadi pada $\mathrm{pH}$ 8. $\mathrm{H}_{2} \mathrm{O}_{2}$ dalam pengolahan lindi dengan sistem $\mathrm{UV} / \mathrm{H}_{2} \mathrm{O}_{2}$ baik dengan maupun tanpa penambahan katalis $\mathrm{TiO}_{2}$ dapat meningkatkan efektivitas penyisihan BOD dan COD lindi. Semakin lama waktu reaksi AOP, semakin meningkat efektivitas penyisihan BOD dan $C O D$ dalam sistem $\mathrm{UV} / \mathrm{H}_{2} \mathrm{O}_{2}$ maupun sistem $\mathrm{UV} / \mathrm{H}_{2} \mathrm{O}_{2} / \mathrm{TiO}_{2}$.
\end{abstract}

Kata kunci: degradasi, lindi, oksidasi lanjut

\begin{abstract}
The objectives of this research were to know (1) leachate characteristic at TPA Bengkala Singaraja based on $\mathrm{BOD}_{5} / \mathrm{COD}$ ratio; the influence of $\mathrm{TiO}_{2}$ catalyst to the effectiveness of $B O D$ and $C O D$ degradation with advanced oxidation process $U \mathrm{UV}^{-} \mathrm{H}_{2} \mathrm{O}_{2}$; (3) the influence of $\mathrm{pH}$ to the effectiveness of $\mathrm{BOD}$ and $\mathrm{COD}$ degradation; (4) the influence of $\mathrm{H}_{2} \mathrm{O}_{2}$ to the effectiveness of BOD and COD degradation; (5) the optimum of time reaction to BOD and COD value. This research was experimented by degraded leachate in photochemical reactor either with or without catalyst addition. The result show that the leachate which was taken from landfill cell at TPA Bengkala Singaraja almost have mature age based on $\mathrm{BOD}_{5} / \mathrm{COD}$. $\mathrm{TiO}_{2}$ addition can increase the effectiveness of $\mathrm{BOD}$ and $\mathrm{COD}$. Effectiveness of $B O D$ and $\mathrm{COD}$ degradation with $\mathrm{UV} / \mathrm{H}_{2} \mathrm{O}_{2}$ are reached at $\mathrm{pH} 8 . \mathrm{H}_{2} \mathrm{O}_{2}$ addition on leachate treatment with $\mathrm{UV} / \mathrm{H}_{2} \mathrm{O}_{2}$ or $\mathrm{UV} / \mathrm{H}_{2} \mathrm{O}_{2} / \mathrm{TiO}_{2}$ can increase the effectiveness of $B O D$ and $C O D$ degradation. The longer reaction time of $A O P$ gives the effectiveness of $\mathrm{BOD}$ and $\mathrm{COD}$ degradation more increase with $\mathrm{UV} / \mathrm{H}_{2} \mathrm{O}_{2}$ as well as $\mathrm{UV} / \mathrm{H}_{2} \mathrm{O}_{2} / \mathrm{TiO}_{2}$ system.
\end{abstract}

Keywords: advanced oxidation, degradation, leachate 


\section{PENDAHULUAN}

Laju pertumbuhan ekonomi pada tahun-tahun terakhir ini menimbulkan ekses timbulan sampah perkotaan yang telah diidentifikasi sebagai salah satu persoalan lingkungan paling serius di dunia dan membutuhkan perhatian serius bagi kepentingan perlindungan lingkungan ( $\mathrm{Li}$, et al., 2010). Lebih dari 95\% sampah di dunia ditimbun dengan metode landfilling (Deng and Englehardt, 2007). Sebagian besar metode landfilling yang diterapkan adalah open dumping atau open landfiling terutama untuk perkotaan di negara-negara yang sedang berkembang. Namun demikian, pengelolaan sampah dengan cara open landfill (penimbunan terbuka) saat ini sudah mulai ditinggalkan. Pengelolaan dengan penimbunan terbuka ini dapat menimbulkan berbagai persoalan baik penurunan kualitas ekologis maupun kesehatan manusia. Gas landfill dan lindi (leachate) yang dihasilkan dari landfill dapat mencemari udara, air, dan tanah. Timbunan sampah secara terbuka juga merupakan tempat berkembangbiaknya organisme penyebar penyakit sehingga dapat menimbulkan gangguan terhadap kesehatan manusia disamping yang diakibatkan dari penurunan kualitas ekologis.

Saat ini metode sanitary landfill telah banyak mendapatkan perhatian. Hal ini terkait dengan keamanan dan keefektifan dari metode landfilling ini. Secara umum sanitary landfilling dilakukan dengan cara: 1) sampah dimasukkan ke dalam lahan yang sudah dilengkapi fundamen yang kedap air dan saluran lindi dan gas, 2) dipadatkan, 3) ditutup dengan tanah penutup, 4) dipadatkan lagi, 5) di atasnya ditempatkan sampah lagi, dan demikian seterusnya. Sejalan dengan amanat Undang-undang No. 18 tahun 2008 tentang Pengelolaan
Sampah, sebagian besar pemerintah kota/kabupaten di Indonesia telah mengupayakan untuk menerapkan metode sanitary landfill untuk penimbunan sampahnya. Namun demikian, pengelolaan sanitary landfill tersebut belum dilakukan secara optimal terutama berkaitan dengan pengolahan lindi (leachate) yang telah dikumpulkan. Fenomena ini juga terjadi di Tempat Pembuangan Akhir (TPA) Bengkala Kubutambahan Singaraja. Lindi di TPA Bengkala Kubutambahan Singaraja sangat keruh, berbau, dan berwarna hitam. Lindi tersebut juga menyebabkan rasa gatal pada kulit. Walaupun cukup jauh dari pemukiman penduduk, dikawatirkan dapat mencemari mata air tanah di daerah tersebut, karena TPA Bengkala berada pada posisi lebih tinggi dari pemukiman penduduk. Indikasi ini menunjukkan diperlukan pengolahan lindi lebih lanjut sehingga tidak menimbulkan permasalahan. Lindi sebagai ouput selain gas landfill yang dihasilkan dari dekomposisi terhadap sampah organik biodegradable baik pada pengolahan dengan cara open dumping maupun sanitary landfill belum dilakukan penanganan secara maksimal.

Pada dasarnya, konsep sanitary landfill dimaksudkan untuk melakukan penanganan secara lebih baik dari kedua ouput tersebut. Dalam hal ini, pada sanitary landfill dilengkapi dengan sarana pengumpulan gas dan lindi yang tidak tersedia pada open landfill. Bila gas dan lindi yang telah dikumpulkan tersebut tidak tertangani dengan baik, akhirnya berbagai persoalan lingkungan dapat ditimbulkan. Khusus untuk lindi bila tidak tertangani dengan baik dapat menimbulkan pencemaran terhadap air permukaan maupun air tanah.

Lindi adalah effluent yang berupa cairan yang dihasilkan sebagai konsekuensi 
dari perkolasi air hujan melewati sampah, proses biokimia di dalam sampah dan kandungan air dari sampah. Perkolasi air hujan ini akan mengekstrak, melarutkan, dan membantu dekomposisi sampah secara biologik sehingga baik material biologik maupun bahan-bahan kimia akan terbawa. Oleh karena itu lindi merupakan campuran yang komplek yang terdiri dari bahan-bahan organik terlarut dan kontaminan-kontaminan anorganik, diantaranya meliputi; asam lemak volatil, senyawa-senyawa fulvat dan humat, logam berat, bahan-bahan organik xenobiotik dan garam-garam anorganik. Komposisi dan konsentrasi kontaminankontaminan tersebut tergantung pada karakteristik dari sampah yang ditimbun, kondisi lokasi, iklim, durasi air yang terinfiltrasi, $\mathrm{pH}$, tingkat pemadatan sampah, dan lain-lain (Renou et al., 2008 dalam Li et al., 2010).

Berbagai upaya atau penelitian berkaitan dengan pengolahan lindi telah dilakukan. Studi-studi laboratorium untuk menentukan keefektifan dari berbagai proses pengolahan secara biologi, fisik, dan kimia pada lindi telah diinvestigasi sejak awal tahun 1970an. Proses-proses pengolahan secara biologi meliputi proses aerobik dan anaerobik cukup efektif untuk lindi dengan rasio BOD (biochemical oxygen demand)/COD (chemical oxygen demand) tinggi yang dihasilkan pada tahap awal landfill ( $\mathrm{Li}$ et al., 2010). Namun demikian, cara ini umumnya gagal untuk mengolah lindi dengan rasio $\mathrm{BOD}_{5} / \mathrm{COD}$ rendah, atau lindi dengan kandungan logam-logam toksik yang tinggi (Deng and Englehardt, 2007). Lebih lanjut ditegaskan oleh Cortez et al. (2010), metode ini tidak efektif untuk mengolah lindi dari umur landfill yang sudah matang (5-10 tahun) karena kandungan bahan organik rekalsitannya lebih tinggi dan rasio BOD/COD rendah (umumnya kurang dari 0,3 ). Oleh karena itu, proses-proses psikokimia digunakan sebagai lanjutan dari proses biologi atau digunakan sebagai pengolahan secara penuh sejak prapengolahan (Li et al., 2010).

Diantara berbagai jenis pengolahan secara fisika-kimia, proses oksidasi lanjut (advanced oxidation processes, AOP) dilaporkan sebagai salah satu metode yang paling efektif untuk mendegradasi berbagai senyawa dalam lindi baik yang dapat didegradasi maupun yang sukar dibiodegradasi (Abbas et al., 2009). Hal ini disebabkan oleh keberadaan radikal hidroksil $(\cdot \mathrm{OH})$ sebagai oksidan yang dihasilkan sistem AOP seperti dari aksi sinergis: antara dua oksidan $\left(\mathrm{O}_{3}+\mathrm{H}_{2} \mathrm{O}_{2}\right)$, suatu katalis dengan suatu oksidan $\left(\mathrm{Fe}^{2+}+\mathrm{H}_{2} \mathrm{O}_{2}\right)$ (reagen Fenton), suatu fotokatalis dangan oksidan $\left(\mathrm{TiO}_{2}+\mathrm{H}_{2} \mathrm{O}_{2}\right)$, iradiasi dengan oksidan: $\mathrm{UV}+\mathrm{O}_{3} / \mathrm{H}_{2} \mathrm{O}_{2}$ ), atau fotokatalis dengan oksidan dan iradiasi $\mathrm{TiO}_{2} /$ $\mathrm{H}_{2} \mathrm{O}_{2} / \mathrm{UV}$, dan lain-lain (Wang et al., 2003 dalam Abbas et al., 2010). Dengan potensial oksidasi $\left(E_{0}=2,80 \mathrm{~V}\right)$, radikal $\cdot \mathrm{OH}$ dapat mengoksidasi bahan-bahan organik rekalsitran seperti senyawa-senyawa aromatik, terklorinasi, dan phenolik.

Pada awalnya, AOP banyak digunakan untuk pengolahan limbah industri. Misalnya, keefektifan dari reagen Fenton sebagai salah satu AOP untuk mendekolorisasi zat warna tekstil dan menurunkan COD limbah rumah pemotongan hewan telah diamati secara berturut-turut oleh Yuningrat dan Putra (2006) dan Yuningrat dan Gunamantha (2007). Namun demikian, beberapa penelitian terkait pengolahan lindi dengan menggunakan AOP telah banyak dilakukan seperti: Petruzzelli et al. (2006) menggunakan reagen Fenton sebagai 
pengolahan awal, Cortez et al. (2010) menggunakan sistem berbasis ( $\mathrm{Fe}^{2+} / \mathrm{H}_{2} \mathrm{O}_{2} / \mathrm{UV}$ dan $\mathrm{H}_{2} \mathrm{O}_{2} / \mathrm{UV}$ ) untuk pengolahan awal lindi dari landfill yang sudah matang, Tengrui et al. (2007) mempelajari pengaruh kondisi operasi seperti waktu, $\mathrm{pH}$, rasio $\mathrm{H}_{2} \mathrm{O}_{2} / \mathrm{Fe}(\mathrm{II})$ dan temperatur terhadap efektivitas proses Fenton untuk pengolahan lindi dari landfill yang sudah tua. Penelitian-penelitian tersebut belum menunjukkan hasil yang efektif terutama berkaitan dengan kemampuan untuk mendegradasi seyawasenyawa rekalsitran. Hal ini ditunjukkan oleh rasio $\mathrm{BOD} / \mathrm{COD}$ yang dihasilkan masih rendah yaitu pada rentangan 0,21 hingga 0,42 .

Untuk meningkatkan hasil akhir rasio $\mathrm{BOD} / \mathrm{COD}$, perlu dipertimbangkan penggunaan $A O P$ berbasis sistem $\mathrm{TiO}_{2} / \mathrm{H}_{2} \mathrm{O}_{2} / \mathrm{UV}$ untuk meningkatkan konsentrasi radikal $\cdot \mathrm{OH}$. Penggunaan sistem kombinasi $\mathrm{UV} / \mathrm{H}_{2} \mathrm{O}_{2} / \mathrm{TiO}_{2}$ memang belum pernah dilakukan untuk pengolahan lindi, tetapi telah digunakan untuk meningkatkan biodegradabilitas klorophenol pada air limbah (Kuo, 2009) dan peningkatan laju degradasi terhadap phenol dan $p$ klorophenol (Dixit et al., 2010). Hasil penelitian baik yang dilakukan oleh Kuo maupun Dixit merekomendasikan bahwa kombinasi ini direkomendasikan sebagai suatu pendekatan untuk mendegradasi senyawa-senyawa rekalsitran. Dijelaskan bahwa, elektron pada pita konduksi dan lubang pada pita valensi yang terdapat pada titanium dioksida akan menyerap sinar UV (Banerjee (2006); Stasinasikis (2008). Adanya $\mathrm{H}_{2} \mathrm{O}_{2}$ akan meningkatkan jumlah akseptor elektron sehingga semakin meningkatkan pula jumlah radikal bebas yang dihasilkan (Benerjee, 2006).
Berdasarkan permasalahan tersebut di atas maka secara lebih rinci masalah tersebut dapat dirumuskan sebagai berikut: (1) Bagaimanakah karakteristik lindi di TPA Bengkala Singaraja berdasarkan rasio $\mathrm{BOD}_{5} / \mathrm{COD}$ ?; (2) Bagaimanakah pengaruh penambahan katalis $\mathrm{TiO}_{2}$ terhadap efektivitas penyisihan BOD dan COD lindi dengan menggunakan proses oksidasi lanjut (AOP) sistem UV/ $\mathrm{H}_{2} \mathrm{O}_{2}$ ?; (3) Bagaimanakah pengaruh $\mathrm{pH}$ campuran terhadap efektivitas penyisihan $\mathrm{BOD}$ dan $\mathrm{COD}$ lindi dengan menggunakan proses oksidasi lanjut (AOP)?; (4) Bagaimanakah pengaruh konsentrasi $\mathrm{H}_{2} \mathrm{O}_{2}$ terhadap efektivitas penyisihan $\mathrm{BOD}$ dan $\mathrm{COD}$ lindi dengan menggunakan proses oksidasi lanjut (AOP)?; (5) Bagaimanakah pengaruh waktu reaksi terhadap nilai $B O D$ dan $C O D$ lindi dengan menggunakan proses oksidasi lanjut?

\section{METODE}

Penelitian ini diawali dengan pembuatan reaktor fotokimia dan pengambilan sampel lindi. Selanjutnya, lindi direaksikan dengan $\mathrm{H}_{2} \mathrm{O}_{2}$ dan diaduk serta diberikan sinar UV selama 90 menit. Pengolahan lindi dilakukan dengan memvariasi $\mathrm{pH}$ larutan $6,7,8$; konsentrasi $\mathrm{H}_{2} \mathrm{O}_{2} 10 \mathrm{~mL} / \mathrm{L}, 12 \mathrm{~mL} / \mathrm{L}, 14 \mathrm{~mL} / \mathrm{L}$, tanpa maupun dengan penambahan $\mathrm{TiO}_{2}$ sebanyak $1 \mathrm{~g} / \mathrm{L}$ lindi. Setiap interval waktu 45 menit dilakukan pengambilan sampel lindi yang telah diolah dengan proses oksidasi lanjut kemudian dianalisis BOD dan CODnya.

Subjek penelitian adalah lindi yang diambil dari saluran pengeluaran cell landfill di TPA Bengkala Singaraja. Lindi dimasukkan dalam botol glass sawo pada temperatur $4{ }^{\circ} \mathrm{C}$ dan dibawa ke laboratorium untuk diolah dengan menggunakan proses 
oksidasi lanjut. Pengaruh penambahan $\mathrm{TiO}_{2}$, $\mathrm{pH}$ larutan, konsentrasi $\mathrm{H}_{2} \mathrm{O}_{2}$ dan waktu reaksi dipelajari untuk mengevaluasi nilai BOD dan COD lindi. Alat-alat yang digunakan dalam penelitian ini: reaktor fotokimia yang terbuat dari pyrex, jerigen plastik warna hitam, botol BOD, inkubator, DO meter, $\mathrm{pH}$ meter, neraca analitik, seperangkat alat refluks dan titrasi, pemanas, termometer, jerigen besar, magnetik stirrer, COD reaktor, penyaring, desikator, spektrofotometer, alat distilasi, stop watch dan alat-alat gelas laboratorium. Bahan-bahan yang digunakan adalah $\mathrm{H}_{2} \mathrm{O}_{2}$ $32 \% \mathrm{w} / \mathrm{v}$ buatan Merck, $\mathrm{KMnO}_{4}, \mathrm{AlCl}_{3}$, $\mathrm{NaOH}, \mathrm{H}_{2} \mathrm{SO}_{4}, \mathrm{FeSO}_{4}, \mathrm{~K}_{2} \mathrm{Cr}_{2} \mathrm{O}_{7}, \mathrm{Ag}_{2} \mathrm{SO}_{4}$, $\mathrm{HgSO}_{4}, \mathrm{FAS}$ dan indikator feroin, $\mathrm{TiO}_{2}$ (Degussa P-25), dan kertas saring Whatman filter selulosa asetat $0,45 \mu \mathrm{m}$. Semua bahan kimia yang digunakan berkualitas analisis.

Nilai BOD dan COD yang diperoleh dari setiap perlakuan disajikan dalam bentuk tabel dan grafik. Grafik yang dibuat menyajikan pengaruh penambahan $\mathrm{TiO}_{2}, \mathrm{pH}$ larutan, dan konsentrasi $\mathrm{H}_{2} \mathrm{O}_{2}$ terhadap efektivitas penyisihan $\mathrm{BOD}$ dan $\mathrm{COD}$, serta pengaruh waktu reaksi terhadap nilai COD.

HASIL

Hasil pengukuran nilai BOD dan COD dari lindi yang diolah dengan menggunakan proses oksidasi lanjut (AOP) sistem $\mathrm{H}_{2} \mathrm{O}_{2} / \mathrm{UV}$ disajikan dalam Tabel 1 dan 2.

Tabel 1. Nilai BOD untuk sistem tanpa katalis (sistem $\mathrm{H}_{2} \mathrm{O}_{2} / \mathrm{UV}$ )

\begin{tabular}{cccc}
\hline \multicolumn{2}{c}{ Variabel } & \multicolumn{2}{c}{ BOD } \\
\hline $\mathrm{pH}$ & $\begin{array}{c}\mathrm{H}_{2} \mathrm{O}_{2} \\
(\mathrm{~mL} / \mathrm{L})\end{array}$ & $\begin{array}{c}0 \\
\text { menit }\end{array}$ & $\begin{array}{c}90 \\
\text { menit }\end{array}$ \\
\hline 6 & 10 & 76,70 & 49,20 \\
6 & 14 & 83,40 & 38,50 \\
7 & 12 & 72,20 & 49,70 \\
\hline
\end{tabular}

\begin{tabular}{llll}
\hline 8 & 10 & 74,60 & 41,70 \\
8 & 14 & 72,50 & 40,10 \\
\hline
\end{tabular}

Tabel 2. Nilai COD untuk sistem tanpa katalis (sistem $\mathrm{H}_{2} \mathrm{O}_{2} / \mathrm{UV}$ )

\begin{tabular}{ccccc}
\hline \multicolumn{3}{c}{ Variabel } & \multicolumn{3}{c}{$\mathrm{COD}$} \\
\hline $\mathrm{pH}$ & $\begin{array}{c}\mathrm{H}_{2} \mathrm{O}_{2} \\
\mathrm{~mL} / \mathrm{L}\end{array}$ & $\begin{array}{c}0 \\
\text { menit }\end{array}$ & $\begin{array}{c}45 \\
\text { menit }\end{array}$ & $\begin{array}{c}90 \\
\text { menit }\end{array}$ \\
\hline 6 & 10 & 489,60 & 475,20 & $\begin{array}{c}379,2 \\
0\end{array}$ \\
6 & 14 & 462,34 & 369,60 & $\begin{array}{c}340,8 \\
0\end{array}$ \\
7 & 12 & 456,00 & 398,40 & $\begin{array}{c}316,8 \\
0\end{array}$ \\
8 & 10 & 427,20 & 321,60 & $\begin{array}{c}307,2 \\
0\end{array}$ \\
8 & 14 & 513,60 & 398,40 & $\begin{array}{c}340,8 \\
0\end{array}$ \\
\hline
\end{tabular}

Hasil pengukuran nilai BOD dan COD dari lindi yang diolah dengan menggunakan proses oksidasi lanjut (AOP) dengan adanya penambahan katalis $\mathrm{TiO}_{2}$ (sistem $\mathrm{H}_{2} \mathrm{O}_{2} / \mathrm{UV}$ / $\mathrm{TiO}_{2}$ ) disajikan dalam Tabel 3 dan 4.

Tabel 3. Nilai BOD untuk sistem dengan adanya $\mathrm{TiO}_{2} 1 \mathrm{~g} / \mathrm{L}$ (sistem $\mathrm{H}_{2} \mathrm{O}_{2} / \mathrm{UV} / \mathrm{TiO}_{2}$ )

\begin{tabular}{cccc}
\hline \multicolumn{2}{c}{ Variabel } & \multicolumn{2}{c}{ BOD } \\
\hline $\mathrm{pH}$ & $\begin{array}{c}\mathrm{H}_{2} \mathrm{O}_{2} \\
(\mathrm{~mL} / \mathrm{L})\end{array}$ & $\begin{array}{c}0 \\
\text { menit }\end{array}$ & $\begin{array}{c}90 \\
\text { menit }\end{array}$ \\
\hline 6 & 10 & 81,60 & 46,20 \\
6 & 14 & 71,50 & 42,60 \\
7 & 12 & 67,70 & 38,00 \\
8 & 10 & 66,10 & 40,90 \\
8 & 14 & 75,20 & 47,60 \\
\hline
\end{tabular}

Tabel 4. Nilai COD untuk sistem dengan adanya $\mathrm{TiO}_{2} 1 \mathrm{~g} / \mathrm{L}$ (sistem $\mathrm{H}_{2} \mathrm{O}_{2} / \mathrm{UV} / \mathrm{TiO}_{2}$ )

Variabel $\mathrm{COD}$




\begin{tabular}{ccccc}
\hline $\mathrm{pH}$ & $\mathrm{H}_{2} \mathrm{O}$ & 0 & 45 & 90 \\
& 2 & menit & menit & menit \\
& $\mathrm{L}$ & & & \\
\hline 6 & 10 & 456,00 & 369,60 & 340,80 \\
6 & 14 & 523,20 & 369,60 & 357,50 \\
7 & 12 & 504,00 & 465,60 & 350,40 \\
8 & 10 & 456,00 & 369,60 & 288,00 \\
8 & 14 & 460,61 & 350,40 & 235,20 \\
\hline
\end{tabular}

\section{PEMBAHASAN}

Berdasarkan hasil analisis kandungan $\mathrm{BOD}_{5}$ dan $\mathrm{COD}$ sebelum diberikan perlakuan, dapat dilihat bahwa kandungan zat organik dalam lindi termasuk tingkat menengah bila dinyatakan sebagai COD. Namun, bila dilihat berdasarkan tingkat biodegradabilitasnya, maka lindi yang digunakan dalam penelitian ini dikategorikan memiliki tingkat biodegradabilitas yang sedang menurut Papadopoulos et al. (2001), dengan perbandingan $\mathrm{COD} / \mathrm{BOD}_{5}$ sebesar 6,38 . Tingkat biodegradabilitas lindi yang diteliti mengindikasikan bahwa pengolahan secara biologi kurang menguntungkan bila dibandingkan pengolahan secara kimia. Usia lindi dalam penelitian ini dapat diketahui dari perbandingan $\mathrm{BOD}_{5} / \mathrm{COD}$ sebesar 0,156 yang mengindikasikan bahwa lindi hampir matang, sehingga dapat dipastikan bahwa kandungan asam humat, asam fulvat maupun zat organik lain tinggi.

Pengaruh penambahan katalis $\mathrm{TiO}_{2}$ pada pengolahan lindi dengan proses oksidasi lanjut (AOP) selama 90 menit terhadap efektivitas penyisihan BOD dan COD disajikan dalam Gambar 1.

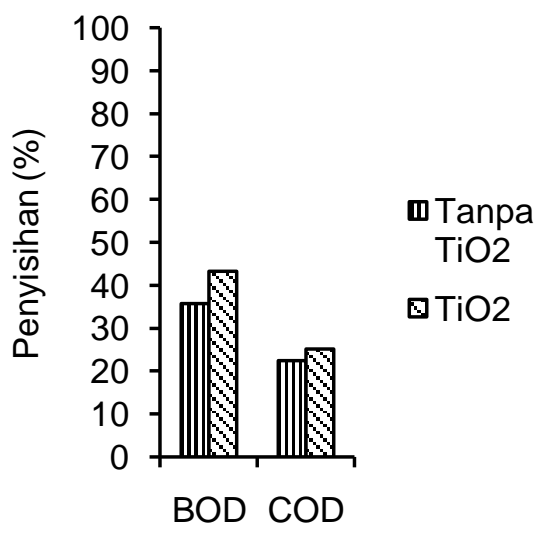

Gambar 1. Pengaruh fotokatalis $\mathrm{TiO}_{2}$ terhadap efektivitas penyisihan BOD dan COD lindi

Gambar 1 menunjukkan bahwa penambahan fotokatalis $\mathrm{TiO}_{2}$ memberikan peningkatan terhadap efektivitas penyisihan BOD dan COD dalam lindi. Peningkatan ini dapat disebabkan oleh telah terdegradasinya zat-zat organik dalam lindi menjadi senyawa yang lebih sederhana.

Nilai BOD dan COD lindi mengalami penurunan dalam sistem yang mengandung lindi dan $\mathrm{H}_{2} \mathrm{O}_{2}$ yang mengalami penyinaran selama 90 menit. Penurunan nilai BOD dan COD dapat disebabkan oleh pengikatan senyawa organik oleh radikal $\mathrm{OH}$, yang dihasilkan oleh $\mathrm{H}_{2} \mathrm{O}_{2}$ setelah menyerap sinar dengan energi yang sesuai. Hal ini mengakibatkan jumlah zat organik menjadi berkurang sehingga kebutuhan oksigen untuk mendegradasi senyawa organik secara biologi dan kimiawi menurun. Atau dengan kata lain, nilai BOD dan COD berkurang.

Sementara itu, keberadaan fotokatalis $\mathrm{TiO}_{2}$ yang menyerap sinar dengan energi yang sesuai dalam sistem reaksi, mengakibatkan terbentuknya hole positif pada pita valensi $\left(\mathrm{h}_{\mathrm{vb}}{ }^{+}\right)$dan pelepasan elektron pada pita konduksi $\left(\mathrm{e}_{\mathrm{cb}}{ }^{-}\right)$, sesuai dengan persamaan reaksi: 


$$
\mathrm{TiO}_{2}+h v \rightarrow \mathrm{e}_{\mathrm{cb}}{ }^{-}+\mathrm{h}_{\mathrm{vb}}{ }^{+}
$$

Selanjutnya, terjadi penjebakan (trapping) hole positif pada pita valensi pada pemukaan katalis membentuk radikal $\cdot \mathrm{OH}$.

$$
\mathrm{h}_{\mathrm{vb}}{ }^{+}+>\mathrm{Ti}^{\mathrm{IV}} \mathrm{OH} \rightarrow\left(>\mathrm{Ti}^{\mathrm{iV}} \mathrm{OH} \cdot\right)^{+}
$$

Radikal $\cdot \mathrm{OH}$ yang terbentuk memiliki potensial sebesar 2,8 eV (Gunlazuardi dalam Prasetya, 2009), dapat menginisiasi reaksi oksidasi senyawa organik yang ada dalam sistem reaksi. Reaksi oksidasi senyawa organik oleh radikal $\cdot \mathrm{OH}$ menghasilkan gas $\mathrm{CO}_{2}$, uap air dan zat-zat organik lain yang lebih sederhana, menurut reaksi berikut:

$$
\cdot \mathrm{OH}+\mathrm{O}_{2}+{ }_{(2 n-2 m+2)}^{\mathrm{CnOmH}} \rightarrow n \mathrm{CO}_{2}+(n-m+
$$

$$
\text { 1) } \mathrm{H}_{2} \mathrm{O}
$$

Sesuai sifat alamiahnya, $\mathrm{e}_{\mathrm{cb}}{ }^{-}$dan $\left(>\mathrm{Ti}^{\mathrm{IV}} \mathrm{OH} \cdot\right)^{+}$dapat bergabung kembali (berekombinasi) sehingga jumlah radikal $\cdot \mathrm{OH}$ akan berkurang. Namun, keberadaan $\mathrm{H}_{2} \mathrm{O}_{2}$ dalam sistem reaksi dapat mencegah rekombinasi antara ecb- dan $\left(>\mathrm{Ti}^{\mathrm{lV}} \mathrm{OH} \cdot\right)^{+}$, dengan cara mengikat $e_{c b}$ sehingga jumlah radikal $\cdot \mathrm{OH}$ tetap terjaga banyak. Selain diikat oleh $\mathrm{H}_{2} \mathrm{O}_{2}$, pengikatan $\mathrm{e}_{\mathrm{cb}}{ }^{-}$juga dilakukan oleh $\mathrm{O}_{2}$ yang dialirkan ke dalam sistem. Reaksi pengikatan $\mathrm{e}_{\mathrm{cb}}{ }^{-}$oleh $\mathrm{H}_{2} \mathrm{O}_{2}$ dan $\mathrm{O}_{2}$ adalah sebagai berikut.

$$
\begin{aligned}
& \mathrm{H}_{2} \mathrm{O}_{2}+\mathrm{e}_{\mathrm{cb}}^{-} \rightarrow \cdot \mathrm{OH}+\mathrm{OH}^{-} \\
& \mathrm{O}_{2}+\mathrm{e}_{\mathrm{cb}}{ }^{-} \rightarrow \mathrm{O}_{2}^{-} \cdot
\end{aligned}
$$

Selain itu, faktor ukuran senyawa organik dimungkinkan mempengaruhi mudah tidaknya senyawa organik masuk ke dalam pori $\mathrm{TiO}_{2}$ dan kemudian bereaksi dengan radikal $\cdot \mathrm{OH}$ sehingga senyawa organik mengalami fotodegradasi. Molekul senyawa organik yang berukuran lebih kecil akan lebih mudah masuk ke dalam pori $\mathrm{TiO}_{2}$ dan akhirnya akan lebih banyak senyawa organik yang terfotodegradasi.

Oleh karena itu, penambahan fotokatalis $\mathrm{TiO}_{2}$ meningkatkan jumlah radikal . $\mathrm{OH}$ dalam sistem reaksi sehingga degradasi senyawa organik menjadi semakin efektif. Jumlah senyawa organik yang semakin berkurang dalam sistem menyebabkan penurunan nilai BOD dan COD sehingga efektivitas penyisihan BOD dan COD juga semakin meningkat.

Pengaruh $\mathrm{pH}$ dalam sistem reaksi dilakukan dengan memvariasi $\mathrm{pH}$ campuran sebelum proses oksidasi lanjut lindi selama 90 menit. Pengaruh $\mathrm{pH}$ terhadap efektivitas penyisihan $\mathrm{BOD}$ dalam sistem tanpa maupun ada katalis disajikan dalam Gambar 2 dan 3.

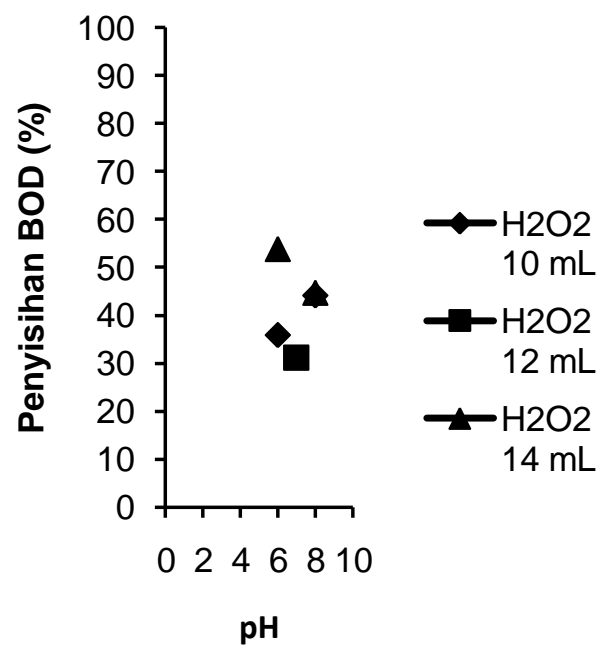

Gambar 2. Pengaruh $\mathrm{pH}$ terhadap efektivitas penyisihan $\mathrm{BOD}$ tanpa fotokatalis $\mathrm{TiO}_{2}$ 


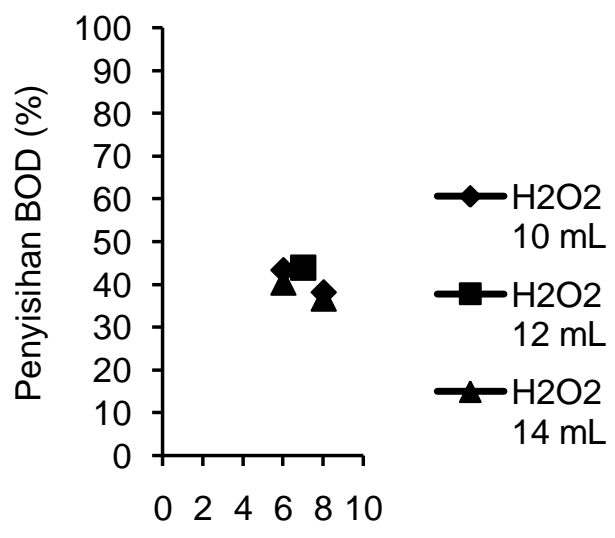

$\mathrm{pH}$

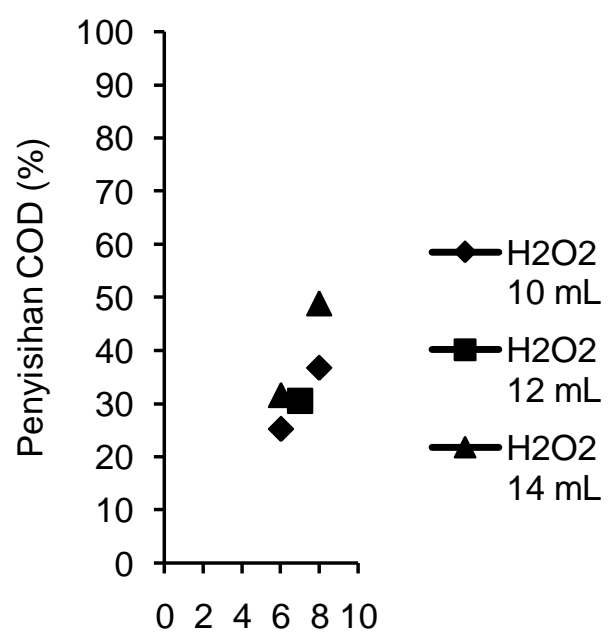

$\mathrm{pH}$

Gambar 3. Pengaruh $\mathrm{pH}$ terhadap efektivitas penyisihan $\mathrm{BOD}$ dengan adanya katalis $\mathrm{TiO}_{2}$

Dari Gambar 2 dan 3 dapat
diketahui bahwa kecenderungan efektivitas penyisihan BOD pada $\mathrm{pH} 6$ sampai 8 untuk sistem tanpa maupun dengan fotokatalis $\mathrm{TiO}_{2}$ relatif sama. Kecenderungan tersebut adalah efektivitas penyisihan BOD berkurang seiring dengan kenaikan $\mathrm{pH}$. Untuk pengaruh $\mathrm{pH}$ terhadap efektivitas penyisihan COD disajikan dalam Gambar 4 dan 5.

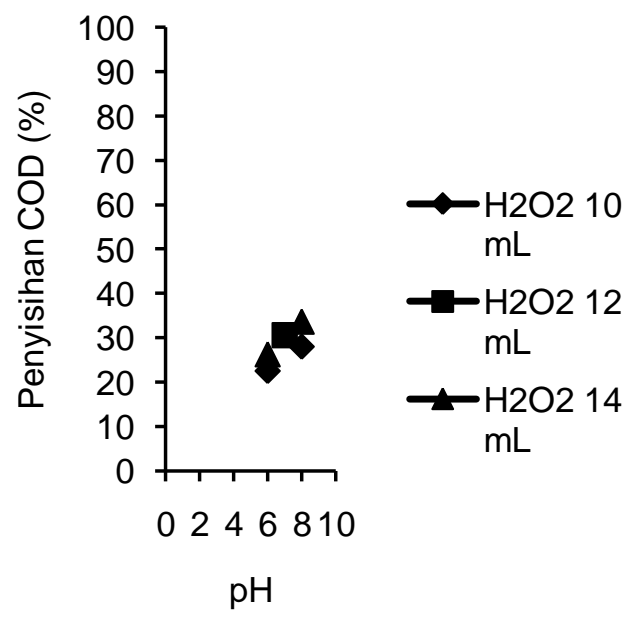

Gambar 4. Pengaruh $\mathrm{pH}$ terhadap efektivitas penyisihan COD tanpa fotokatalis $\mathrm{TiO}_{2}$
Gambar 5. Pengaruh pH terhadap efektivitas penyisihan COD dengan fotokatalis $\mathrm{TiO}_{2}$

Dari Gambar 4 dan 5 dapat diketahui bahwa kecenderungan efektivitas penyisihan COD pada pH 6 sampai 8 untuk sistem tanpa maupun dengan fotokatalis $\mathrm{TiO}_{2}$ relatif sama. Kecenderungan tersebut adalah terjadi peningkatan efektivitas penyisihan COD lindi seiring dengan kenaikan $\mathrm{pH}$ dari 6 sampai 8 .

Pada kondisi $\mathrm{pH}$ campuran bersifat basa, $\mathrm{H}_{2} \mathrm{O}_{2}$ akan bereaksi dengan $\mathrm{OH}^{-}$ menghasilkan anion hidroperoksil $\left(\mathrm{HO}_{2}^{-}\right)$. Selanjutnya, anion $\mathrm{HO}_{2}^{-}$akan bereaksi dengan sisa $\mathrm{H}_{2} \mathrm{O}_{2}$. Reaksi ini disamping menghasilkan $\mathrm{H}_{2} \mathrm{O}$ dan $\mathrm{O}_{2}$, juga menghasilkan radikal $\cdot \mathrm{OH}$ sehingga jumlah radikal $\cdot \mathrm{OH}$ semakin bertambah dalam sistem. Reaksi yang terjadi adalah sebagai berikut.

$$
\begin{aligned}
& \mathrm{H}_{2} \mathrm{O}_{2}+\mathrm{OH}^{-} \rightarrow \mathrm{HO}_{2}^{-}+\mathrm{H}_{2} \mathrm{O} \\
& \mathrm{H}_{2} \mathrm{O}_{2}+\mathrm{HO}_{2}^{-} \rightarrow \mathrm{H}_{2} \mathrm{O}+\mathrm{O}_{2}+\cdot \mathrm{OH}
\end{aligned}
$$

Radikal $\cdot \mathrm{OH}$ yang terbentuk mengikat senyawa organik sehingga mengalami 
fotodegradasi. Pada range $\mathrm{pH}$ 6-14, permukaan $\mathrm{TiO}_{2}$ berbentuk $>\mathrm{TiO}^{-}$yang memiliki kemampuan membentuk radikal . $\mathrm{OH}$ dan elektron yang lebih rendah dibanding spesies $>\mathrm{TiOH}$. (Hoffman et al. dalam Prasetya, 2009). Meskipun radikal $\cdot \mathrm{OH}$ yang dihasilkan dari $\mathrm{TiO}_{2}$ sedikit, akan tetapi cukup tersedia oleh radikal $\cdot \mathrm{OH}$ yang berasal dari $\mathrm{H}_{2} \mathrm{O}_{2}$. Selain itu, pada daerah $\mathrm{pH}$ ini senyawa organik berada dalam bentuk yang mudah terdegradasi sehingga degradasi semakin efektif.

Oleh karena itu, harga $\mathrm{pH}$ sistem sangat menentukan spesiasi permukaan senyawa organik, katalis $\mathrm{TiO}_{2}$ maupun $\mathrm{H}_{2} \mathrm{O}_{2}$ dalam larutan. Spesiasi tersebut mempengaruhi kemudahan senyawa organik mengalami degradasi, fotokatalis $\mathrm{TiO}_{2}$ dalam menyediakan hole pada pita valensi $\left(\mathrm{h}_{\mathrm{vb}}{ }^{+}\right)$dan radikal $\cdot \mathrm{OH}$, maupun $\mathrm{H}_{2} \mathrm{O}_{2}$ menghasilkan radikal $\cdot \mathrm{OH}$. Dari Gambar 4 dan 5 dapat diketahui bahwa efektivitas penyisihan COD yang maksimum diperoleh pada $\mathrm{pH}$ 8. Pada $\mathrm{pH}$ tersebut, baik fotokatalis $\mathrm{TiO}_{2}$ maupun $\mathrm{H}_{2} \mathrm{O}_{2}$ menghasilkan radikal $\cdot \mathrm{OH}$, dan senyawa organik berada dalam bentuk yang mudah terdegradasi. Hal inilah yang menyebabkan nilai COD minimum sehingga menghasilkan efektivitas penyisihan COD yang optimal.

Dari Gambar 2, 3, 4 dan 5 dapat diketahui bahwa kenaikan konsentrasi $\mathrm{H}_{2} \mathrm{O}_{2}$ memberikan peningkatan efektivitas penyisihan BOD maupun COD. Semakin tinggi konsentrasi $\mathrm{H}_{2} \mathrm{O}_{2}$ maka semakin banyak radikal $\mathrm{OH}$ yang dihasilkan sehingga degradasi senyawa organik semakin efektif. Berkurangnya senyawa organik dalam sistem menyebabkan semakin sedikit kebutuhan oksigen untuk mendegradasi sehingga nilai BOD dan COD rendah, akibatnya efektivitas penyisihan $B O D$ dan $C O D$ semakin meningkat.
Keberadaan $\mathrm{H}_{2} \mathrm{O}_{2}$ yang menyerap sinar dengan energi yang sesuai menghasilkan radikal $\cdot \mathrm{OH}$, menurut reaksi:

$$
\mathrm{H}_{2} \mathrm{O}_{2}+h v \rightarrow 2 \cdot \mathrm{OH}
$$

Konsentrasi $\mathrm{H}_{2} \mathrm{O}_{2}$ yang semakin tinggi akan menghasilkan jumlah radikal $\cdot \mathrm{OH}$ yang semakin banyak. Selain itu, $\mathrm{H}_{2} \mathrm{O}_{2}$ juga dapat berperan sebagai akseptor elekron sehingga dapat mencegah rekombinasi dan meningkatkan jumlah radikal $\cdot \mathrm{OH}$. Reaksi fotolisis $\mathrm{H}_{2} \mathrm{O}_{2}$ dan peran ganda $\mathrm{H}_{2} \mathrm{O}_{2}$ menyebabkan degradasi senyawa organik dalam lindi menjadi semakin efektif.

Namun, jika konsentrasi $\mathrm{H}_{2} \mathrm{O}_{2}$ di dalam larutan terlalu tinggi maka $\mathrm{H}_{2} \mathrm{O}_{2}$ juga dapat bereaksi dengan $\mathrm{h}_{\mathrm{vb}}{ }^{+}$dan radikal $\cdot \mathrm{OH}$. Reaksi yang tejadi adalah sebagai berikut.

$$
\begin{aligned}
& \mathrm{H}_{2} \mathrm{O}_{2}+\mathrm{h}_{\mathrm{vb}}{ }^{+} \rightarrow \mathrm{O}_{2}+2 \mathrm{H}^{+} \quad(9) \\
& \mathrm{H}_{2} \mathrm{O}_{2}+\cdot \mathrm{OH} \rightarrow \mathrm{H}_{2} \mathrm{O}+\mathrm{HO}_{2} \cdot \\
& \mathrm{HO}_{2} \cdot+\cdot \mathrm{OH} \rightarrow \mathrm{H}_{2} \mathrm{O}+\mathrm{O}_{2}
\end{aligned}
$$

Pengikatan $\mathrm{h}_{\mathrm{vb}}{ }^{+}$dan radikal $\cdot \mathrm{OH}$ oleh $\mathrm{H}_{2} \mathrm{O}_{2}$ yang berlebihan manyebabkan jumlah radikal $\mathrm{OH}$ berkurang sehingga fotodegradasi senyawa organik berjalan lambat. Jumlah senyawa organik yang masih banyak dalam sistem mengakibatkan kebutuhan oksigen untuk mendegradasi senyawa organik yang semakin besar, sehingga nilai BOD dan COD relatif tinggi. Hal ini dapat menyebabkan efektivitas penyisihan BOD dan COD lindi menjadi turun.

Dari Gambar 2, 3, 4 dan 5 dapat diketahui bahwa efektivitas penyisihan BOD dan COD yang optimum untuk pengolahan lindi dengan proses oksidasi lanjut, baik tanpa maupun dengan adanya katalis $\mathrm{TiO}_{2}$ diperoleh dengan $\mathrm{H}_{2} \mathrm{O}_{2} 14 \mathrm{~mL}$ untuk setiap 1 liter lindi. 
Pengaruh waktu reaksi pengolahan lindi dalam sistem AOP dengan maupun tanpa penambahan fotokatalis $\mathrm{TiO}_{2}$ terhadap nilai COD disajikan dalam Gambar 6.

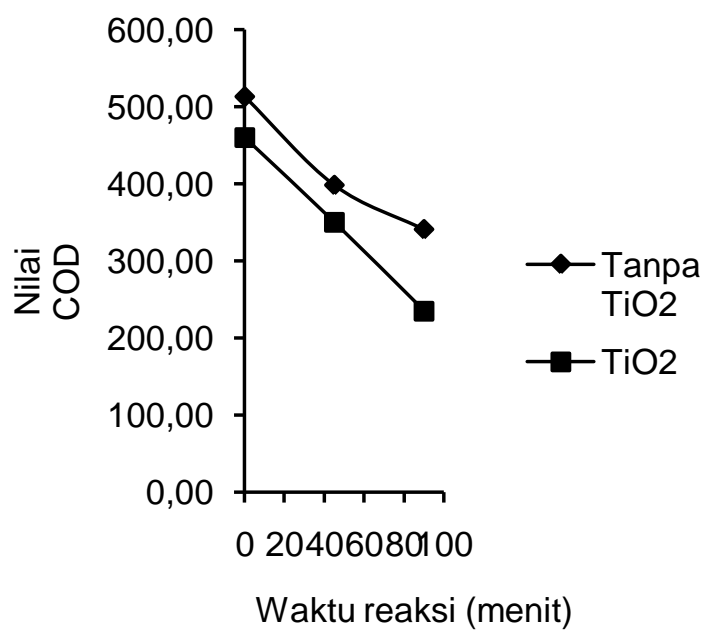

Gambar 6. Pengaruh waktu reaksi terhadap nilai $\mathrm{COD}$ lindi pada $\mathrm{pH} 8$ dan

$$
\mathrm{H}_{2} \mathrm{O}_{2} 14 \mathrm{~mL}
$$

Gambar 6 menunjukkan bahwa semakin lama waktu reaksi untuk pengolahan lindi dengan sistem AOP tanpa maupun dengan adanya penambahan katalis $\mathrm{TiO}_{2}$ memberikan penurunan nilai COD. Penurunan nilai COD mengindikasikan bahwa sebagian kandungan senyawa organik yang terdapat dalam lindi telah mengalami fotodegradasi. Reaksi AOP dengan waktu yang semakin lama menyebabkan kandungan zat organik menjadi berkurang sehingga jumlah oksigen yang diperlukan untuk mendegradasi senyawa organik secara kimiawi semakin berkurang. Akibatnya, waktu reaksi yang semakin lama memberikan nilai COD yang semakin rendah.

Dari Gambar 6 dapat diketahui bahwa sistem yang mengandung lindi, $\mathrm{H}_{2} \mathrm{O}_{2}$ dan katalis $\mathrm{TiO}_{2}$ yang dikenai sinar UV selama 90 menit memberikan penurunan nilai COD lindi yang tajam. Waktu reaksi yang semakin lama menyebabkan interaksi antara $\mathrm{H}_{2} \mathrm{O}_{2}$ dengan sinar, dan $\mathrm{TiO}_{2}$ dengan sinar semakin efektif sehingga radikal $\cdot \mathrm{OH}$ yang dihasilkan dari fotolisis $\mathrm{H}_{2} \mathrm{O}_{2}$ dan penjebakan (trapping) lubang dengan permukaan terhidrat $\mathrm{TiO}_{2} \quad\left(>\mathrm{Ti}^{\mathrm{IV}} \mathrm{OH}\right)$ juga semakin banyak. Jumlah radikal $\cdot \mathrm{OH}$ yang banyak dengan waktu penyinaran yang lama menghasilkan reaksi antara radikal - $\mathrm{OH}$ dengan senyawa organik yang semakin efektif, sehingga kandungan senyawa organik dalam sistem semakin berkurang. Berkurangnya jumlah zat organik dalam sistem menyebabkan berkurangnya kebutuhan oksigen untuk mendegaradasi zat organik secara kimiawi sehingga nilai COD lindi semakin menurun.

\section{SIMPULAN DAN SARAN}

Berdasarkan penelitian yang telah dilakukan maka dapat diperoleh simpulan sebagai berikut (1) lindi yang diambil dari cell landfill di TPA Bengkala Singaraja memiliki usia yang hampir matang berdasarkan perbandingan $\mathrm{BOD}_{5} / \mathrm{COD}$; (2) penambahan katalis $\mathrm{TiO}_{2}$ untuk pengolahan lindi dengan menggunakan proses oksidasi lanjut (AOP) sistem $\quad \mathrm{UV} / \mathrm{H}_{2} \mathrm{O}_{2}$ dapat meningkatkan efektivitas penyisihan $\mathrm{BOD}$ dan COD lindi; (3) efektivitas penyisihan BOD dan COD lindi dengan menggunakan proses oksidasi lanjut sistem $\mathrm{UV} / \mathrm{H}_{2} \mathrm{O}_{2}$ mencapai maksimum pada $\mathrm{pH}$ campuran yang bersifat basa; (4) adanya $\mathrm{H}_{2} \mathrm{O}_{2}$ dalam pengolahan lindi dengan sistem $\mathrm{UV} / \mathrm{H}_{2} \mathrm{O}_{2}$ baik dengan maupun tanpa penambahan katalis $\mathrm{TiO}_{2}$ dapat meningkatkan efektivitas penyisihan BOD dan COD lindi; (5) waktu reaksi $A O P$ yang semakin lama dapat meningkatkan efektivitas penyisihan $\mathrm{BOD}$ 
dan COD dalam sistem $\mathrm{UV} / \mathrm{H}_{2} \mathrm{O}_{2}$ maupun sistem $\mathrm{UV} / \mathrm{H}_{2} \mathrm{O}_{2} / \mathrm{TiO}_{2}$. Oleh karena itu, perlu dilakukan penelitian lebih lanjut untuk $\mathrm{pH}$ campuran yang lebih tinggi dari 8, waktu reaksi yang lebih dari 90 menit dan konsentrasi $\mathrm{H}_{2} \mathrm{O}_{2}$ yang lebih tinggi dari 14 $\mathrm{mL} / \mathrm{L}$ lindi dalam proses degradasi senyawa organik dalam lindi, sehingga dapat diketahui efektivitas penyisihan BOD dan COD yang optimum. Selain itu, untuk memastikan bahwa zat-zat organik dalam lindi telah terdegradasi dengan baik maka perlu dilakukan analisis senyawa organik yang terkandung dalam lindi, baik sebelum maupun setelah pengolahan lindi pada proses oksidasi lanjut $\mathrm{UV} / \mathrm{H}_{2} \mathrm{O}_{2} / \mathrm{TiO}_{2}$.

\section{UCAPAN TERIMA KASIH}

Terima kasih kepada Universitas Pendidika Ganesha yang telah membiayai penelitian ini melalui dana DIPA Tahun 2011.

\section{DAFTAR PUSTAKA}

Banerjee, S., Gopal, J., Muraleedharan, P., Tyagi1, A.K., and Raj, B. 2006. Physics and chemistry of photocatalytic titanium dioxide: Visualization of bactericidal activity using atomic force microscopy. Current Science, vol. 90, no. 10, 25 May 2006

Cortez, S., Teixeira, P., Oliveira, R., and Mota, M. 2010. Fenton's Oxidation as Post-Treatment of a Mature Municipal Landfill Leachate. International Journal of Civil and Environmental Engineering 2:1 2010

Deng, Y. and Englehardt, J.D. 2007. Electrochemical oxidation for landfill leachate treatment Waste Management, vol. 27, no. 3, pp. 38038.

Dixit, A., Mungray, A.K., and Chakraborty, M. 2010. Photochemical Oxidation of Phenol and Chlorophenol by $\mathrm{UV} / \mathrm{H}_{2} \mathrm{O}_{2} / \mathrm{TiO}_{2}$ Process: A Kinetic
Study. International Journal of Chemical Engineering and Applications, Vol. 1, No. 3, October 2010 ISSN: 2010-0221

Kuo, W.S., and Lin, I.T. 2009. Biodegradability of chlorophenol wastewater enhanced by solar photofenton process. vol. 59, pp. 973-978

Li, W., Zhou, Q., and Hua1, T. 2010. Review ArticleRemoval of Organic Matter from Landfill Leachate by Advanced Oxidation Processes: A Review. International Journal of Chemical Engineering Volume 2010, Article ID 270532, $\quad 10$ pages doi:10.1155/2010/270532

Prasetya, N.B. 2009. Pemanfaatan buah ketimun (Cucumis sativus) sebagai sumber asam oksalat dan penambahan ion $\mathrm{Fe}(\mathrm{III})$ untuk meningkatkan efektivitas fotoreduksi ion $\mathrm{Cr}(\mathrm{VI})$ terkatalisis $\mathrm{TiO}_{2}$. Tesis. Universitas Gadjah Mada.

Petruzzelli, D., Boghetich, G., Patrelia, M., Abbate, P.L., Sanarica, S., Miraglia, M., 2006. 2006. Pre-treatment of Industrial Landfill Leachate by Fenton's Oxidation. Global NEST Journal, Vol X, No X, pp XX-XX, 2006. Copyright@ 2006 Global NEST. Printed in Greece

Staasinakis, A.S. 2008. Use of Selected Advanced Oxidation Processes (AOPs) For Wastewater Treatment A Mini Review. Global NEST Journal, Vol 10, No 3, pp 376-385, 2008

Tengrui, L., Al-Harbawi, A., Jun, Z., dan Bo, L.M. 2007. The effect its Influence Factors of the Fenton Process on the Old Landfill Leachate. Journal of Applied Sciences 7 (5) 724-727

Yuningrat dan Putra.S. 2006. Dekolorisasi Air Limbah Pencelupan Tekstil dengan Dekomposisi Katalitik Hidrogen Peroksida dalam Besi Oksida. Laporan Penelitian Dosen Muda

Yuningrat dan Gunamantha. 2007. Studi Pengolahan Limbah Cair Rumah Potong Hewan dengan Reagen Fenton untuk Menurunkan COD dan 
BOD (Studi Kasus Limbah Rumah Pemotongan Hewan Kabupaten Badung Bali). Laporan Penelitian Dosen Muda 